\title{
MMC Converter Cells Employing Ultrahigh-Voltage SiC Bipolar Power Semiconductors
}

\author{
Keijo Jacobs, Daniel Johannesson, Staffan Norrga, Hans-Peter Nee \\ KTH Royal Institute of Technology, EES/EPE \\ SE-100 44 Stockholm, Sweden \\ Phone: +46 (0) 762935411 \\ Email: keijoj@kth.se, djohann@kth.se,norrga@kth.se, hansi@kth.se
}

\section{Acknowledgments}

The authors would like to acknowledge SweGRIDS for funding this project and ABB Corporate Research Center (SECRC) for their valuable support.

\section{Keywords}

$\ll$ HVDC transmission $\gg, \ll$ Modular multilevel converters $\gg, \ll$ Silicon carbide $\gg$

\begin{abstract}
This paper investigates the benefits of using high-voltage converter cells for transmission applications. These cells employ ultrahigh-voltage SiC bipolar power semiconductors, which are optimized for low conduction losses. The Modular Multilevel Converter with half-bridge cells is used as a test case. The results indicate a reduction of converter volume and complexity, while maintaining low losses and harmonic performance.
\end{abstract}

\section{Introduction}

Silicon carbide $(\mathrm{SiC})$ as a wide bandgap semiconductor material for power electronic devices has a variety of advantages to the well-established silicon (Si) technology: higher blocking voltages, faster switching, and better heat conductivity. Nevertheless, a plug and play solution into existing technology does not unleash its full potential. The voltage of Modular Multilevel Converter (MMC) cells is mainly limited by the blocking voltage of the semiconductor devices. A series connection of devices increases the blocking voltage, but not without additional measures to distribute the voltage equally among the devices, and possibly a need for higher safety margins. Current MMC cells without series connection of devices may employ high voltage Si semiconductors with blocking voltages of $3.3 \mathrm{kV}$ up to $6.5 \mathrm{kV}$. They are operated at approximately half the blocking voltage, meaning a maximum of $3.25 \mathrm{kV}$ in the latter case. Ultrahigh-voltage (UHV) SiC bipolar devices are foreseen to be suitable for blocking voltages up to $50 \mathrm{kV}$ [1][2]. Consequently, the maximum operation voltage of converter cells could be increased by a factor of almost eight. As a result, the amount of cells needed in modular HVDC converters could be reduced by that factor. This may come with certain benefits, such as reduction of converter volume, reduced complexity, increased reliability, lower converter losses, and lower investment cost. Also the use of cells with different voltages in the same arm is a possibility. Modulation strategies for that case have been presented in [3]. This paper will first describe the general concept of such high-voltage SiC-based cells and the simplified conduction characteristic of UHV SiC devices. Subsequently, the aforementioned aspects are discussed and challenges as well as differences to existing concepts described.

\section{Ultrahigh-voltage $\mathrm{SiC}$ devices}

$\mathrm{SiC}$ devices with high blocking voltage can replace a stack of devices used in cells with series-connected $\mathrm{Si}$ devices. Recent advances in $\mathrm{SiC}$ manufacturing technologies have generated state-of-art research 
prototype semiconductor devices with high blocking voltage capabilities. SiC MOSFETs have reached $15 \mathrm{kV}$ blocking voltage capability [4]. Bipolar SiC devices have reached beyond $20 \mathrm{kV}$ blocking voltage capability in research laboratories, for example 7-39 kV PiN diodes [5], $27.5 \mathrm{kV}$ integrated-gate bipolar transistors (IGBT) [6], $20 \mathrm{kV}$ gate turn-off thyristors (GTO) [7], and $22 \mathrm{kV}$ Emitter turn-off (ETO) thyristors [8].

The electrical characteristics of UHV semiconductor devices (i.e., SiC IGBT and SiC GTO above $30 \mathrm{kV}$ ) have recently been evaluated in [1]. Here, the theoretical performance of these non-existing devices has been predicted and compared using different modeling approaches. It is assumed that the influence of the circuit (gate resistance and stray inductance) on the switching characteristics is negligible. This implies ideal switching conditions. Within this model, a parametric sensitivity analysis is performed to investigate the impact on device characteristics for a number of key parameters, such as charge carrier lifetimes, current densities and different temperatures. This modeling approach has been implemented within this study and details are given in [1].
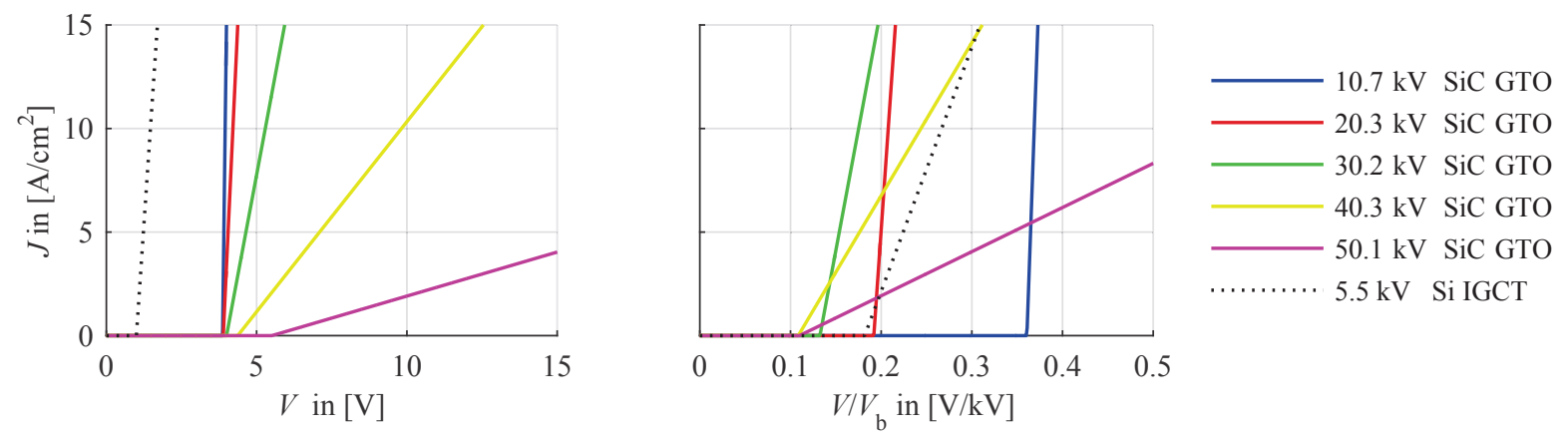

Fig. 1: Linearized V-I characteristic of SiC GTO designs from [1] using "mixed Baliga and Huang" model (left) and their characteristic normalized to blocking voltage (right). Si IGCT [9] for comparison
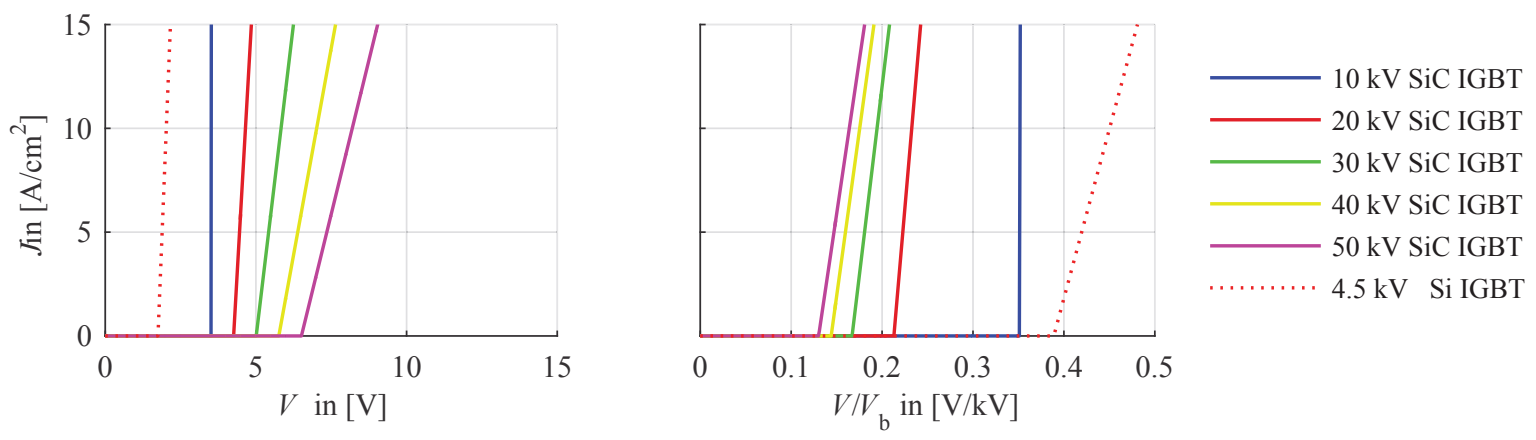

Fig. 2: Linearized V-I characteristic of SiC IGBT designs from [1] (left) and their characteristic normalized to blocking voltage (right). Si IGBT [10] for comparison

MMCs with sufficient amount of levels have the advantage that a low switching frequency of approximately 2-3 times the fundamental frequency can be used without harmonic limitations. Thyristor-based devices, which are advantageous in terms of conduction losses, are a suitable fit. The main drawback of bipolar $\mathrm{SiC}$ devices regarding conduction losses is the higher knee voltage, i.e. the voltage drop due to the built-in potential. When designing a converter, there will be a break-even point for the use of series connection of $\mathrm{Si}$ devices and the use of a single $\mathrm{SiC}$ device. For certain cell voltages, the on-state losses of a UHV SiC bipolar device will be lower than those of a series connection of Si devices. The effect is illustrated in Fig. 1 for thyristor-based devices, and in Fig. 2 for IGBTs. A comparison between theoretical $\mathrm{SiC}$ device characteristics, computed in [1], and their already existing Si counterparts is given. The current density $J$ is plotted over the on-state voltage. The disadvantage of the high knee voltage is diminished for higher blocking voltages. On the other hand, higher blocking voltages require a thicker drift region, which increases the resistive part of the on-state voltage. The $\mathrm{SiC}$ devices' characteristic has 
been computed with a carrier lifetime of $10 \mu$ s [1]. An optimum in conduction losses can be seen for a blocking voltage between $30 \mathrm{kV}$ and $35 \mathrm{kV}$. Such a device would have significantly lower on-state losses than a series connection of Si integrated gate commutated thyristors (IGCTs).

\section{High-voltage cell concept}

Increasing the cell voltage reduces the amount of cells required per converter arm. This results in a reduction of converter complexity and auxiliary electronics (gate drivers, auxiliary power supply, control hardware, etc). As a test case, the cell voltage was increased by a factor of ten, from $1650 \mathrm{~V}$ (conventional $3.3 \mathrm{kV}$ Si IGBT modules) to $16.5 \mathrm{kV}$ (UHV $33 \mathrm{kV} \mathrm{SiC}$ device), as shown in Table I. As mentioned before, thyristor-based semiconductors are a suitable fit for MMCs, due to their superior conduction performance. The use of IGCTs for HVDC converter cells has been experimentally verified in [11]. A comparison between conventional IGBT cells and IGCT cells regarding losses, reliability and cost of the converter has been presented in [12]. Wire-bonded modules (WBM), which are commonly used for IGBTs, fail into an open circuit if exposed to sufficiently high currents. Such a failure might cause an explosion, since the silicone gel within the WBM evaporates. Since IGCTs are implemented in press pack (PP) housing, they feature the advantage of a short-circuit failure mode [13]. PP implementations for IGBTs also exist, however, they are more complex than IGCT implementations, since several smaller chips have to be paralleled.

IGCTs need a series reactor, to limit the slope of the current during switching. This is due to the time the plasma needs to spread across the wafer plane, known as spreading time. If the current rise is not limited, a hot spot might be created close to the gate, at the location where the wafer starts to conduct. The increased temperature at that spot leads to further increase in current, so that the device overheats locally. This may lead to destruction and is known as filamentation. SiC devices are expected to be less sensitive to the phenomenon and investigations have shown that $\mathrm{SiC}$ thyristors turn on more homogeneously than their Si counterparts [14]. Furthermore, $\mathrm{SiC}$ has an increased heat conductivity compared to Si. Since the spreading process is mainly determined by diffusion, this might increase spreading velocity.

Table I: Parameters of MMC converter test case

\begin{tabular}{c|c|ccc}
\hline Converter power & $S$ & \multicolumn{3}{|c}{$1 \mathrm{GW}$} \\
DC voltage (pole-pole) & $V_{\mathrm{dc}}$ & \multicolumn{3}{|c}{$640 \mathrm{kV}$} \\
AC voltage & $V_{\mathrm{ac}}$ & \multicolumn{3}{|c}{$M V_{\mathrm{dc}} / 2$} \\
Modulation index & $M$ & \multicolumn{3}{|c}{$2 / \sqrt{3}$} \\
AC current & $I_{\mathrm{ac}}$ & \multicolumn{3}{|c}{$S / 3 V_{\mathrm{ac}}$} \\
\hline Semiconductor device & & $\mathrm{Si}$ IGBT & $\mathrm{Si} \mathrm{IGCT}$ & $\mathrm{SiC} \mathrm{GTO}$ \\
\hline Blocking voltage & $V_{\mathrm{b}}$ & $3.3 \mathrm{kV}$ & $4.5 \mathrm{kV}$ & $33 \mathrm{kV}$ \\
Cell voltage & $V_{\text {cell }}$ & $1.65 \mathrm{kV}$ & $2.25 \mathrm{kV}$ & $16.5 \mathrm{kV}$ \\
Cells per arm & $N_{\text {cell }}$ & 417 & 285 & 42 \\
\hline
\end{tabular}

The proposed cell topology for high-voltage thyristor-based devices can be seen in Fig. 3. Due to the reactor, an RCD snubber circuit is needed to dissipate the energy stored in $L_{\text {cell }}$ when the cell is commutated from insertion to bypass. The increase of cell voltage to the level of UHV SiC devices comes with an increase of the stored energy in the capacitor. Energy storage requirements for MMCs have been investigated in [15] and a lumped form, (1), for the sizing of the cell capacitors has been proposed in [16]. The parameter $k_{\Delta}$ is the permitted voltage fluctuation of the cell capacitor, in this paper assumed to be $\pm 10 \%$. If the cell voltage is increased, the required capacitance decreases by the same factor. Thus, the stored energy in the capacitor increases by that factor. Since the stored energy is proportional to the volume of the capacitor, the use of $33 \mathrm{kV} \mathrm{SiC}$ devices would increase the capacitor volume per cell by a factor of roughly ten, compared to designs using $3.3 \mathrm{kV}$ IGBTs. The total capacitor volume of the converter remains unchanged, since the amount of cells is reduced by a factor of ten. 


$$
C_{\text {cell }} \geq \frac{1.22|S|}{3 \omega \cdot V_{\mathrm{dc}} \cdot V_{\mathrm{cell}} \cdot k_{\Delta}}
$$

It is possible that di/dt limits of thyristor-based UHV SiC devices will be higher than those of their $\mathrm{Si}$ pendants. High-voltage SiC GTOs for pulsed power applications have achieved di/dt above $8 \mathrm{kA} / \mu \mathrm{s}$ [17]. Since there is no data on di/dt requirements of conduction-optimized UHV SiC bipolar devices available yet, it is assumed that the current slope has to be limited to $1 \mathrm{kA} / \mu \mathrm{s}$, as for current high-voltage Si IGCTs [18]. Hence, the size of $L_{\text {cell }}$ increases linearly with the cell voltage. It might also be determined by the fault handling concept, discussed in the following section.
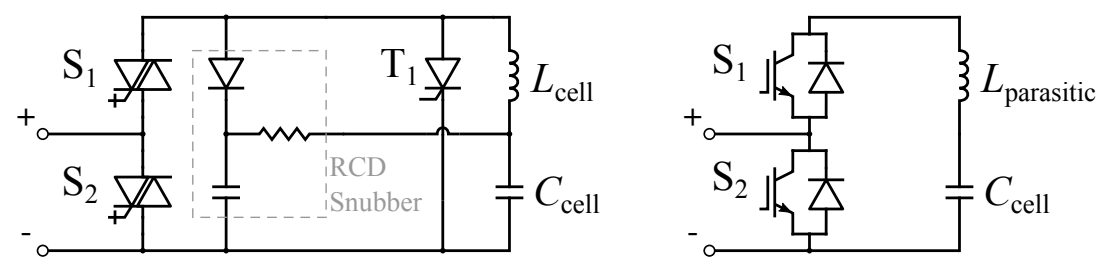

Fig. 3: Thyristor-based half-bridge cell with RCD snubber, di/dt limitation inductor and bypass thyristor (left) and IGBT cell with parasitic inductance (right)

\section{Fault handling concept}

HVDC transmission systems are required to operate reliably between maintenance intervals. Due to the sheer amount of components in such converters, a fault handling concept has to ensure reliable operation of the system, even if components fail (Table II). The cell redundancy needed for an MMC can be determined by the Failure in Time (FIT) rates of the used components, as investigated in [12], where the reliability of a wire-bonded module IGBT implementation and a press pack IGCT implementation has been compared. Until UHV semiconductors are available it is difficult to estimate FIT rates. If these devices achieve similar FIT rates as current Si IGCTs, the reduced amount of auxiliary components will lead to an increase of converter reliability. Due to the low number of cells per arm when using HV cells, the failure of a cell should be avoided at all cost.

Table II: Differences between cell concepts

\begin{tabular}{|c|c|c|c|c|}
\hline Concept & $\begin{array}{l}\text { WBM IGBT } \\
\text { cell }\end{array}$ & PP IGBT cell [19] & $\begin{array}{l}\text { PP IGCT cell, } \\
\text { device stack }\end{array}$ & $\begin{array}{l}\text { PP IGCT cell, } \\
\text { UHV SiC }\end{array}$ \\
\hline Failure mode & Open circuit & Stable short circuit & Stable short circuit & Stable short circuit \\
\hline $\begin{array}{l}\text { Expl.-proof } \\
\text { housing }\end{array}$ & Yes & No & No & No \\
\hline Bypass & at cell terminal & across half-bridge & across half-bridge & across half-bridge \\
\hline $\begin{array}{l}\text { MMC } \\
\text { redundancy }\end{array}$ & add. cells & add. cells & $\begin{array}{l}\text { add. switches in } \\
\text { series connection }\end{array}$ & add. cells \\
\hline Cells per arm & $\frac{V_{\mathrm{dc}}}{V_{\mathrm{b}, \mathrm{Si}}}$ & $\frac{V_{\mathrm{dc}}}{V_{\mathrm{b}, \mathrm{Si}}}$ & $\frac{V_{\mathrm{dc}}}{n_{\mathrm{ser}} V_{\mathrm{b}, \mathrm{Si}}}$ & $\frac{V_{\mathrm{dc}}}{V_{\mathrm{b}, \mathrm{SiC}}}$ \\
\hline $\mathrm{di} / \mathrm{dt}$ reactor & No & No & Yes & Yes \\
\hline
\end{tabular}

At the cell level, shoot-through faults have to be handled in a safe manner. Shoot-through occurs if the cell capacitor is quasi-short-circuited by a failure of the half-bridge. The resulting discharge is a damped oscillation (as seen in Fig. 4) characterized by the cell voltage, cell capacitance, inductance (parasitic or in form of a di/dt reactor), and resistance (of the bus bars and the semiconductors). WBM IGBT failure 


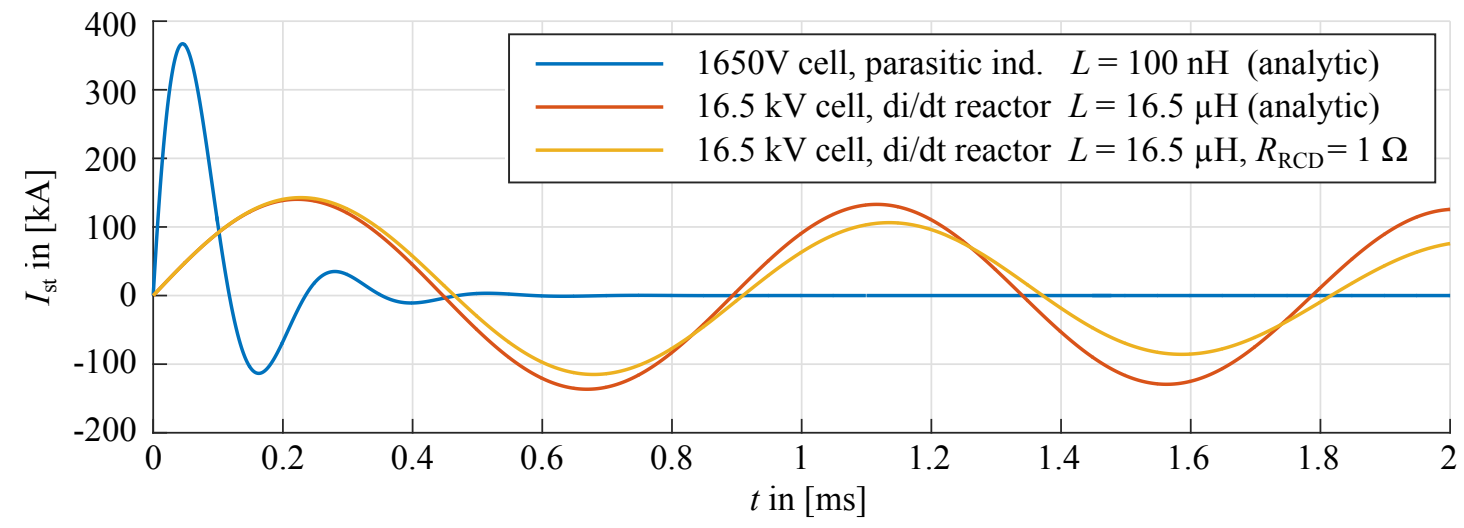

Fig. 4: Simulated shoot-through current for a $1650 \mathrm{~V}$ Si IGBT cell and a $16.5 \mathrm{kV} \mathrm{SiC} \mathrm{GTO} \mathrm{cell}$

comes with arcing and an evaporation of the gel used in the package. Hence, it is necessary to provide an explosion-proof housing for every cell [20]. There is no di/dt limitation reactor needed in IGBT cells. The rise of the shoot-through current is only limited by the parasitic inductance. The subsequent failure of the WBM leads to destruction of the cell.

An inherent protection for thyristor-based cells is the di/dt reactor. Instead of designing the reactor according to the di/dt limitation of the semiconductor, the inductance can be chosen higher to decrease maximum surge current. This comes at the cost of increased switching losses, as illustrated in Fig. 6, where the di/dt reactor has been increased up to ten times its otherwise needed value. It is important that the whole loop, including the di/dt reactor, the capacitor, the semiconductor devices, and the bus bar construction is built in a mechanically robust manner, in order to withstand the mechanical forces during shoot-through failures. Such shoot-through current can be seen in Fig. 4. For the 1650 V IGBT cell, a parasitic inductance of $100 \mathrm{nH}$ was assumed. The $16.5 \mathrm{kV} \mathrm{SiC} \mathrm{GTO} \mathrm{cell,} \mathrm{employs} \mathrm{a} 16.5 \mu \mathrm{H}$ reactor (limiting di/dt to $1000 \mathrm{~A} / \mu \mathrm{s}$ ). The resistance of the semiconductor devices behaves non-linearly and arcing introduces another level of complexity. For simplicity the resistance caused by semiconductors has been assumed to be $1 \mathrm{~m} \Omega$ and constant.

The peak current is significantly lower for the SiC GTO cell, despite its higher stored capacitor energy. Commercially available Si IGCTs can survive surges with peak currents of $50 \mathrm{kA}$. It might be possible that future $\mathrm{SiC}$ devices might be capable of surviving, or even turning off, a short-circuit current. If only one device in a half bridge fails, the other could be blocked as soon as the fault is detected. However, until such evidence has been presented it has to be assumed that the complete energy stored in the cell capacitor has to be dissipated. The main issue for designing MMCs with HV cells becomes clear, when combining the energy equation for capacitances and eq. (1):

$$
E_{\text {nom,cell }}=\frac{1}{2} C_{\text {cell }} V_{\text {cell }}^{2}=\frac{1}{2} C_{\text {cell }} \frac{V_{\text {dc }}}{N_{\text {cell }}} V_{\text {cell }} \geq \frac{1.22|S|}{6 \omega \cdot N_{\text {cell }} \cdot k_{\Delta}}
$$

The three parameters to adjust shoot-through energy are converter transmission power, permitted cell voltage fluctuation, and the amount of cells. The energy stored in one $16.5 \mathrm{kV}$ cell designed according to (1) and Table I amounts to $167 \mathrm{~kJ}$, whereas the $1650 \mathrm{~V}$ cell contains $16.7 \mathrm{~kJ}$. The dissipated heat and the mechanical forces during a shoot-through failure can be expected to be very challenging for the cell design. At approximately $0.4 \mathrm{~ms}$, the IGBT cell has already dissipated its entire energy. The high-voltage cell has only dissipated a small fraction of its total energy at this point, $8.8 \mathrm{~kJ}$. The bypass thyristor $\mathrm{T}_{1}$ can be fired to take over the shoot-through current. As seen in Fig. 4, the RCD snubber of thyristor-based cells can also dissipate some of the total energy. This can be adjusted by the choice of the resistance in the snubber. 


\section{MMC semiconductor losses}

MMC efficiency has been pushed far beyond $99 \%$ in the last years. Nevertheless, it is important to mention the loss competitiveness of HV SiC based cells. The semiconductor losses of MMCs with different semiconductors (according to Table I) can be seen in Fig. 5. The $3.3 \mathrm{kV}$ Si IGBT is a WBM from Mitsubishi (CM1500HC-66R) with an integrated diode. The $4.5 \mathrm{kV}$ Si IGCT and diode are PP devices from ABB (5SHY35L4521, 5SDF10H4503). The loss data for the theoretical SiC GTO has been calculated with the formulae from [1], and its active area was scaled to the size of the $4.5 \mathrm{kV}$ Si IGCT. The loss data for the $\mathrm{SiC}$ diode has been computed with empirical formulae given in [21], and scaled to the size of the $4.5 \mathrm{kV}$ Si diode. Note, that the $3.3 \mathrm{kV}$ Si IGBT does not have the same chip area as the other two examples. The MMC loss model is implemented in Matlab. Current and voltage waveforms for one converter arm and all individual submodules are computed, using phase-shifted carrier modulation. Switching and conduction losses are calculated for each semiconductor. The RCD snubber-circuit losses are included in the switching losses and the switching frequency is set to $150 \mathrm{~Hz}$.

The UHV SiC GTO is advantageous in terms of conduction losses, but performs poorly in terms of switching losses. The $\mathrm{SiC}$ device loss data is based on analytical and empirical models, thus purely theoretical. However, it indicates that MMCs employing a low amount of high-voltage cells might be competitive in comparison to todays technologies.
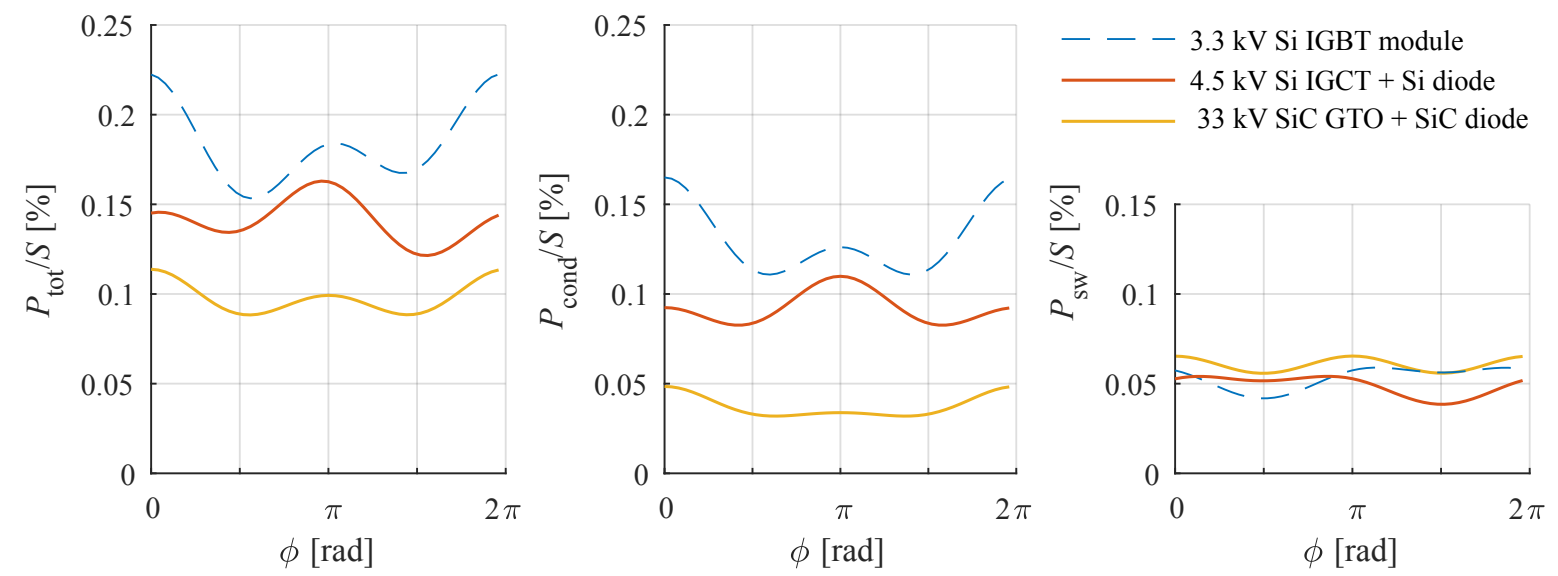

Fig. 5: Semiconductor losses of a half-bridge MMC with specifications given in Table I: total losses (left), conduction losses (middle) and switching losses (right)

\section{Harmonic distortion}

The grid-side current harmonics are partly determined by the converter, and the characteristics of the transformer and the grid. The reduction of the amount of cells in an MMC arm comes with an increase of total harmonic distortion (THD) at the grid connected to the converter. For comparability and simplicity, the arm voltage of the MMC is used as an indicator for harmonic distortion. Phase-shifted carrier modulation has been used and the cell capacitor voltage is assumed constant. For the calculation of THD, only the first 100 harmonics are considered (according to IEC 61000-3-6).

Fig. 7 shows THD as a function of the amount of cells per converter arm. It can be seen that even for a relatively low number of cells the THD is in an acceptable range of approximately $1 \%$. The pulse number can be slightly increased to shift the harmonics to higher frequencies. For even higher pulse numbers a soft switching cell topology, as presented in [22], can be used. Therefore, MMCs with extremely low number of cells per arm $(<40)$ could still maintain acceptable harmonic performance. The sudden drop, seen for $N_{\mathrm{p}}=3.5$ and $N_{\mathrm{p}}=4$ results from harmonics being shifted beyond the order of 100. More detailed simulations have been carried out in [23]. 


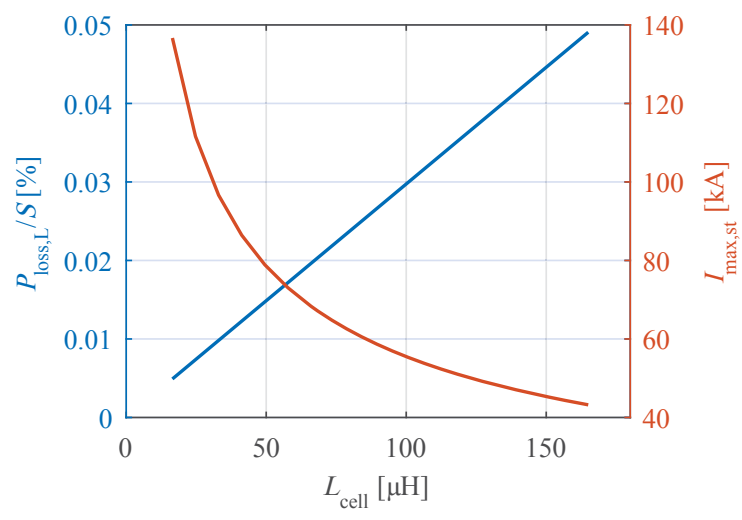

Fig. 6: Losses in RCD snubber due to di/dt reactor for MMC employing $16.5 \mathrm{kV}$ cells as in Fig. 5

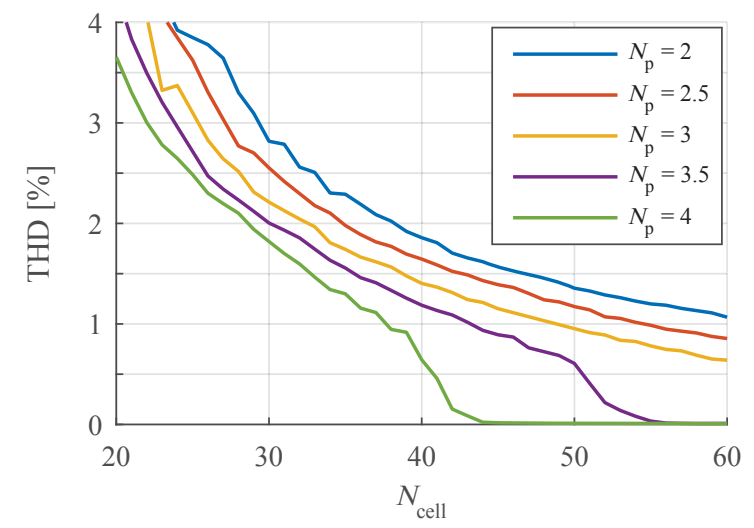

Fig. 7: THD (first 100 harmonics) as a function of $N_{\text {cell }}$, calculated for the arm voltage

\section{Converter volume}

This section gives a comparison of the MMC volume for different converter layouts with specifications according to the Table I. The layouts under discussion can be seen in Fig. 8. Layout (a) is inspired by the most recent MMCs employing $3.3 \mathrm{kV}$ WBM IGBT semiconductors, where the cells are arranged in towers with 72 cells each. Layouts (b) and (c) are proposals for converters with large high-voltage cells. Layout (d) is arranging the arms in a vertical manner, and aims to reduce area footprint. Due to the weight of the cells, this layout is unlikely to be feasible for large converters. It might be feasible for smaller converters with lower power and voltage, or for city infeed, where real-estate prices create a special demand for low area footprint. Due to the lack of comparability to the other layouts, (d) is not included in the following discussion. All layouts follow the general arrangement of arms, depicted in Fig. 9.

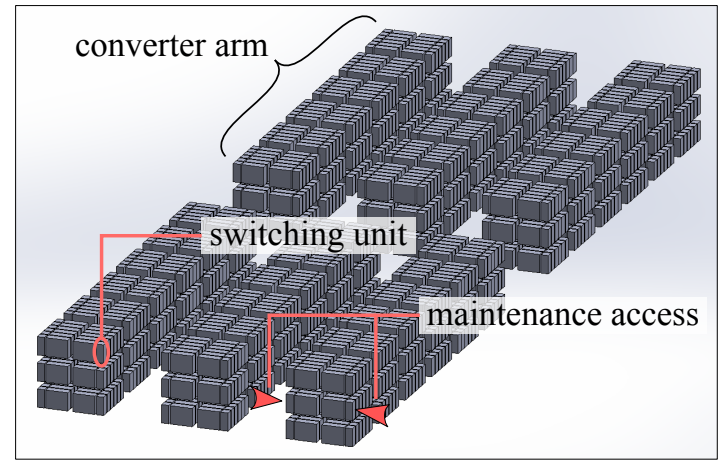

(a)

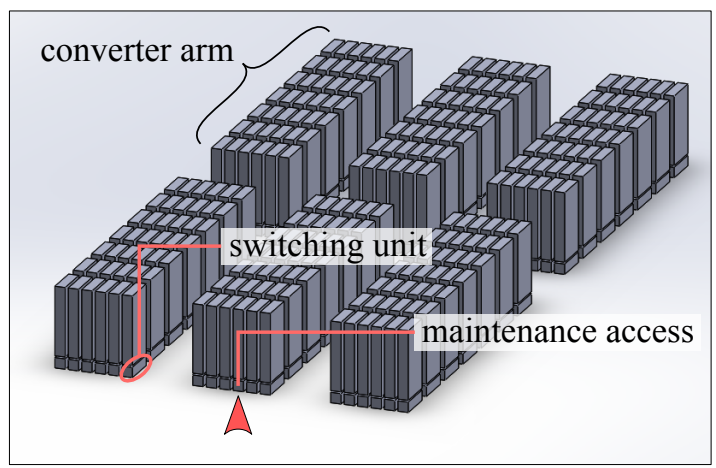

(c)

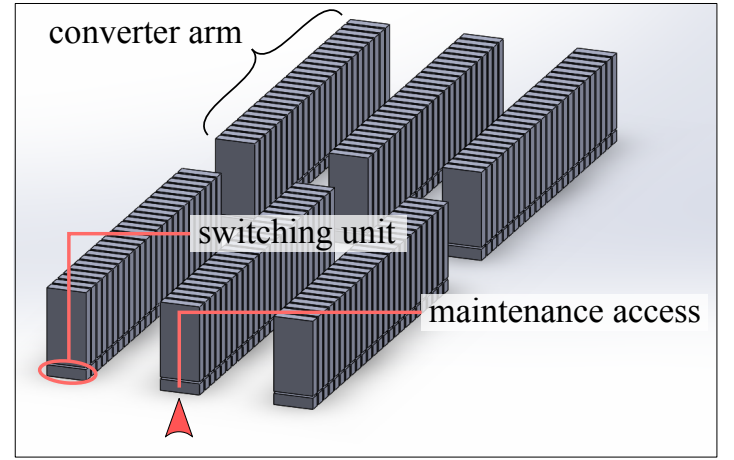

(b)

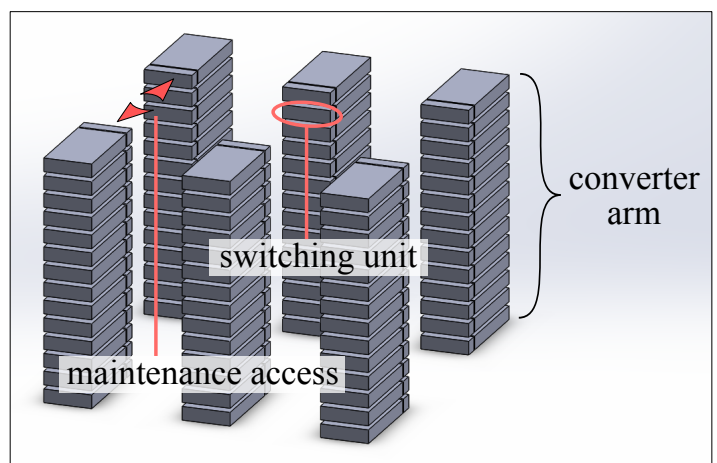

(d)

Fig. 8: Different converter station layouts 
The volume of the converter station is mainly determined by clearances, cell capacitors, maintenance corridors, and the cell switching units. The arm reactor is not included in this comparison. The volume of the switching units (semiconductor devices, drivers, cooling system, control electronics, snubbers) plays a minor role, and it can be assumed that its size does not change significantly for increased cell voltages. Comparing an IGBT WBM cell to an IGCT PP cell it is clear that the IGCT cell will be larger due to additional components i.e. the di/dt reactor, snubber capacitor and diode, and additional space occupied by the mechanical construction of the stack. The IGCT PP switching unit (half bridge) is used for the layouts in this volume comparison. It's dimensions are assumed to be equal $\left(70 \times 30 \times 45 \mathrm{~cm}^{3}\right)$ for all layouts.

As mentioned before, the volume of the sum of all cell capacitors remains unchanged under the assumption that the volume of a capacitor scales linearly with the stored energy. A typical value for capacitor volume per stored energy has been determined $\left(2 \times 10^{-6} \mathrm{~m}^{3} \mathrm{~F}^{-1} \mathrm{~V}^{-2}\right)$ from available datasheets of highvoltage film capacitors by normalizing their volume to capacitance and the square of voltage. The volume of the cell capacitor has been calculated from (1).

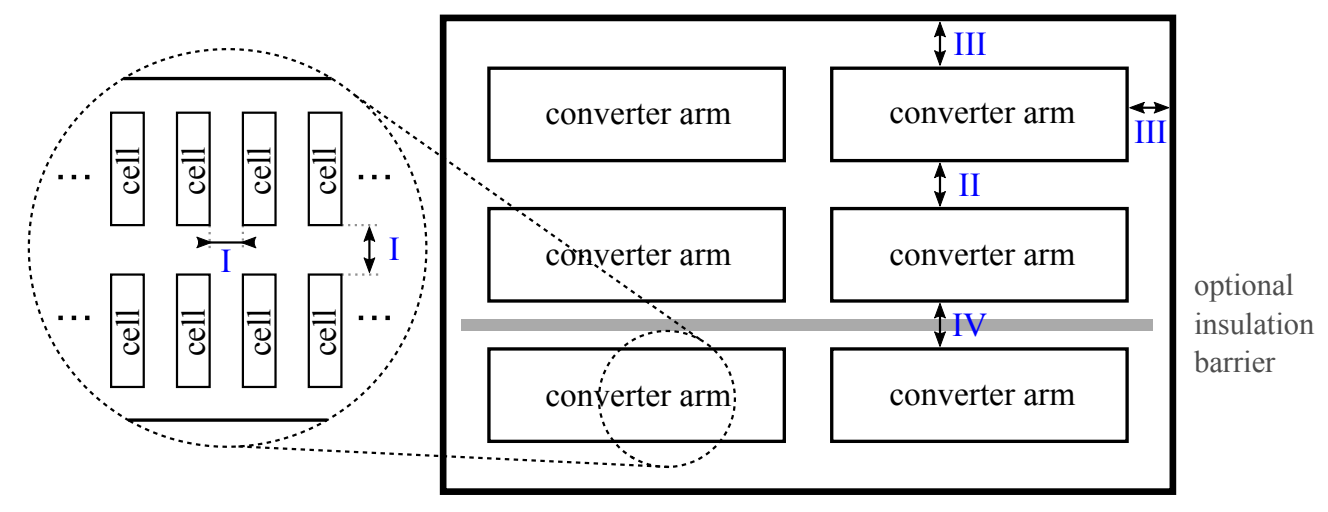

Fig. 9: Top view of MMC station with clearances between cells (I), arms (II), and to walls (III). Insulation barrier reducing the required clearance between arms (IV).

As indicated in Fig. 9, the clearances have been determined for distances between converter cells (I), to bus bars, between converter arms or phases (II), and for distances from arm to wall, ceiling and floor (III). For simplicity a value of $0.55 \mathrm{~cm} / \mathrm{kV}$ is assumed (taken from [24]) and the maximum voltages during normal operation have been used for the calculation. A proper insulation coordination including fault cases and additional safety margins would be too extensive for the scope of this paper. The maximum height of the converter was set to $4 \mathrm{~m}$, plus clearances to floor and ceiling, resulting in $11 \mathrm{~m}$. Maintenance corridors for the exchange of individual cells have been considered, however, necessary clearances are likely to be much larger. Note, that layouts (b) and (c) feature a significant advantage to layout (a): the cells can be accessed and maintained from below the arm, while layout (a) requires access from the side.

The volume and area footprint are shown in Fig. 10. The layouts have an optimum for a certain amount of cells per arm. Layout (b) and (c) are favorable for converters employing a low number of large cells, and (a) is favourable for a high number of small cells. The model indicates a converter volume reduction of approximately $50 \%$ (comparing the cases in Table I). Since arm-to-arm clearances make up for a large portion of the total footprint, a reduction of distance (II) is investigated. This could possibly be achieved with insulation barriers hanging from the ceiling (IV). The layouts with reduced clearances are indicated in Fig. 10 by the addition of "RC". The effect on layout (a) is limited, due to the aforementioned maintenance corridors next to the converter arm, whereas layouts (b) and (c) benefit significantly, leading to additional $10 \%$ of volume reduction. Although this is a simplified analysis, it can be concluded that there is a significant potential for volume reduction. This is possible with layouts used today, by simply reducing the amount of cells and increasing their voltage accordingly. The proposed layouts (b) and (c) benefit from the reduced complexity with high-voltage cells, although only for a small range of $N_{\text {cell }}$. 

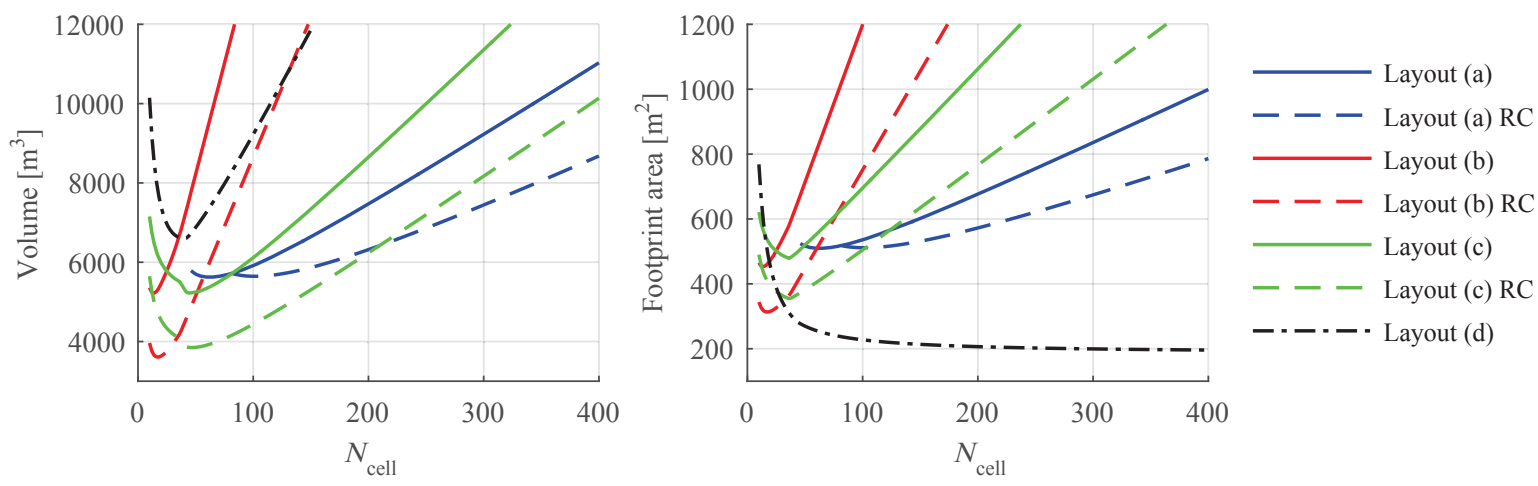

Fig. 10: Volume and area footprint as a function of $N_{\text {cell }}$

\section{Conclusion and future work}

The models used in this paper indicate that UHV SiC bipolar devices enable high-voltage converter cells (without series connection of devices) for HVDC applications. The cell concept features conductionoptimized SiC devices in robust press-pack housings. Furthermore, these cells are shown to be suitable for MMCs. According to the models presented here, there is a potential for converter volume reduction by approximately 50 to $65 \%$, compared to converters employing a large amount of cells. This may translate to reduced real-estate cost and reduced investment cost for structural construction (e.g. converter hall, roof). Furthermore, the points of failure are reduced resulting in better maintainability. Significant improvements in converter reliability could be possible, due to the reduced amount of drivers and auxiliary electronics. These converters are competitive with today's implementations in terms of losses, with expected efficiencies around $99.8 \%$. Harmonics can be controlled to an acceptable level of $1 \%$ THD for a low amount of cells around 40 per converter arm.

\section{References}

[1] D. Johannesson, M. Nawaz, K. Jacobs, S. Norrga, and H.-P. Nee, "Potential of ultra-high voltage silicon carbide semiconductor devices," in Proc. Work. Wide Bandgap Power Devices Appl. (WiPDA 2016), 2016.

[2] T. Kimoto, K. Yamada, H. Niwa, and J. Suda, "Promise and challenges of high-voltage SiC bipolar power devices," Energies, vol. 9, no. 11, p. 908, Nov 2016.

[3] I. Jahn, C. D. Townsend, and H. Z. de la Parra, "Model-predictive modulation strategy for a hybrid Si-SiC cascaded H-bridge multi-level converter," in 2016 18th European Conf. Power Electron. and Applicat. (EPE'16 ECCE Europe), Sept 2016, pp. 1-10.

[4] V. Pala, E. V. Brunt, L. Cheng, M. O'Loughlin, J. Richmond, A. Burk, S. T. Allen, D. Grider, J. W. Palmour, and C. J. Scozzie, "10 kV and $15 \mathrm{kV}$ silicon carbide power MOSFETs for nextgeneration energy conversion and transmission systems," in 2014 IEEE Energy Convers. Congr. Expo. (ECCE), Sep 2014, pp. 449-454.

[5] N. Kaji, H. Niwa, J. Suda, and T. Kimoto, "Ultrahigh-voltage SiC p-i-n diodes with improved forward characteristics," IEEE Trans. Electron Devices, vol. 62, no. 2, pp. 374-381, Feb 2015.

[6] E. van Brunt, L. Cheng, M. J. O'Loughlin, J. Richmond, V. Pala, J. Palmour, C. W. Tipton, and C. Scozzie, "27 kV, 20 A 4H-SiC n-IGBTs," Mater. Sci. Forum, vol. 821-823, pp. 847-850, 2015.

[7] L. Cheng, A. K. Agarwal, C. Capell, O. Loughlin, E. V. Brunt, K. Lam, J. Richmond, A. Burk, and J. W. Palmour, " $20 \mathrm{kV}, 2 \mathrm{~cm} 2$, 4H-SiC gate turn-off thyristors for advanced pulsed power applications," in Plasma Sci. (ICOPS), 2013 Abstr. IEEE Int. Conf., 2013, pp. 1-1. 
[8] X. Song, A. Q. Huang, M. C. Lee, and C. Peng, "Theoretical and experimental study of $22 \mathrm{kV} \mathrm{SiC}$ emitter turn-off (ETO) thyristor," IEEE Trans. Power Electron., vol. 32, no. 8, pp. 6381-6393, Aug 2017.

[9] T. Wikstrom, T. Setz, K. Tugan, T. Stiasny, and B. Backlund, "Introducing the 5.5kV, 5kA HPT IGCT," in PCIM Eur. Conf. Proc., 2012, pp. 881-886.

[10] ABB, “Datasheet 5SMY 12N4500 IGBT-die,” Tech. Rep., 2008.

[11] T. Modeer, S. Norrga, and H.-P. Nee, "Implementation and testing of high-power IGCT-based cascaded-converter cells," in 2014 IEEE Energy Convers. Congr. Expo. (ECCE), Pittsburgh, PA, Sept 2014, pp. 5355-5359.

[12] P. Ladoux, N. Serbia, and E. I. Carroll, "On the potential of IGCTs in HVDC," IEEE J. Emerging Select. Topics Power Electron., vol. 3, no. 3, pp. 780-793, Sept 2015.

[13] F. Dijkhuizen and S. Norrga, "Fault tolerant operation of power converter with cascaded cells," in Proc. 2011 14th European Conf. Power Electron. Applicat., Aug 2011, pp. 1-8.

[14] M. E. Levinshtein, P. A. Ivanov, A. K. Agarwal, and J. W. Palmour, "On the homogeneity of the turn-on process in high-voltage 4H-SiC thyristors," in Solid. State. Electron., vol. 49, no. 2, 2005, pp. 233-237.

[15] K. Ilves, S. Norrga, L. Harnefors, and H.-P. Nee, "On energy storage requirements in modular multilevel converters," IEEE Trans. Power Electron., vol. 29, no. 1, pp. 77-88, Jan 2014.

[16] M. M. C. Merlin and T. C. Green, "Cell capacitor sizing in multilevel converters: cases of the modular multilevel converter and alternate arm converter," IET Power Electron., vol. 8, no. 3, pp. 350-360, Mar 2015.

[17] H. K. OBrien, A. A. Ogunniyi, W. Shaheen, and S. H. Ryu, "Turn-on of high-voltage SiC thyristors for fast-switching applications," IEEE J. Emerging and Select. Topics in Power Electron., vol. 4, no. 3, pp. 772-779, Sept 2016.

[18] ABB, "Datasheet 5SHY 35L4520," Tech. Rep.

[19] H. Chen, W. Cao, P. Bordignon, R. Yi, H. Zhang, and W. Shi, "Design and testing of the world's first single-level press-pack IGBT based submodule for MMC VSC HVDC applications," in 2015 IEEE Energy Conv. Congr. and Expo. (ECCE), Sept 2015, pp. 3359-3366.

[20] M. Billmann, D. Malipaard, and H. Gambach, "Explosion proof housings for IGBT module based high power inverters in HVDC transmission application," in Proc. PCIM Eur. 2009 Conf., Nuremberg, 2009, pp. 352-357.

[21] M. Nawaz, "Predicting potential of 4H-SiC power devices over $10 \mathrm{kV}$," in 2013 IEEE 10th Int. Conf. on Power Electron. and Drive Syst. (PEDS), April 2013, pp. 1291-1296.

[22] M. Heuvelmans, T. Moder, and S. Norrga, "Soft-switching cells for high-power converters," in IECON 2014 - 40th Annu. Conf. IEEE Ind. Electron. Soc., Oct 2014, pp. 1806-1812.

[23] A. Hassanpoor, S. Norrga, H. P. Nee, and L. ngquist, "Evaluation of different carrier-based PWM methods for modular multilevel converters for HVDC application," in IECON 2012 - 38th Annu. Conf. IEEE Ind. Electron. Soc., Oct 2012, pp. 388-393.

[24] T. L. Ong, T. C. Cheng, and N. G. Hingorani, "Survey of creepage distances and clearances in HVDC converter stations," IEEE Trans. Power App. Syst., vol. PAS-104, no. 8, pp. 2255-2265, Aug 1985. 